\title{
THE EFFECT OF TEAM GAME TOURNAMENT (TGT) COOPERATIVE LEARNING METHOD APPLICATION TOWARDS LEARNING MOTIVATION AND ACHIEVEMENT
}

\author{
$\underline{\text { Linda Juwita }}^{1}$, Ni PutuWulanPurnama Sari², Yurike Septianingrum ${ }^{3}$ \\ ${ }^{1}$ Faculty of Nursing, Widya Mandala Catholic University Surabaya, Jl. Raya Kalisari \\ Selatan 1, Pakuwon City, Surabaya, Indonesia \\ ${ }^{2}$ Faculty of Nursing, Widya Mandala Catholic University Surabaya, Jl. Raya Kalisari \\ Selatan 1, Pakuwon City, Surabaya, Indonesia \\ ${ }^{3}$ Faculty of Nursing, NahdlatulUlama University, J1. Raya Jemur Sari No.57, Surabaya, \\ Indonesia
}

\author{
Correspondence Email Addres:lindajuwita73@gmail.com \\ Faculty of Nursing, Widya Mandala Catholic University Surabaya, \\ Jl. Raya Kalisari Selatan 1, Pakuwon City, Surabaya, Indonesia, \\ lindajuwita74@gmail.com, Mobile: +6285237476892, Fax.+623199005278
}

\begin{abstract}
Introduction: Learning method of Team Game Tournament (TGT) has student-centered learning characteristic focuses on students' knowledge construction in which they could find important information useful for constructing their own knowledge. The continuous weak comprehension of neurology system anatomy and physiology resulted in the application of TGT for constructing students' knowledge in this study. This study aimed to analyze the efficacy of TGT application for improving learning motivation and achievement in studying neurology system anatomy and physiology among nursing students. Methods: This pre-experimental study used the one group pretest post-test design approach. Target population was all nursing students in two institutions around Surabaya in the even semester of 2016/2017 academic year. Inclusion criteria were passed the course of Biomedical II or Nursing Basics I. Sample size was 143 chose by total sampling. Independent variable was TGT application and dependent variables were learning motivation and achievement. Study instruments were motivation questionnaire and objective test. Data analysis used paired t test and Mann-Whitney test with $\alpha \leq 0.05$. Ethical clearance was issued (number: 449-KEPK). Results: Most respondents were 19 years old single female who chose nursing major because of their dream, and majority still live with parents in their own house. Only learning motivation data that were normally distributed. TGT application could increase learning motivation and achievement of nursing studentssignificantly ( $\mathrm{p}=0.000$ and $\mathrm{p}=0.028$ respectively). Conclusions: TGT application could increase learning motivation and achievement in studying neurology system anatomy and physiology among nursing students. Further implementation could be broad, other subjects in nursing could be the target in which difficult subject would be underlined.
\end{abstract}

Keywords: team game tournament, learning motivation, learning achievement, nursing education, learning method

\section{INTRODUCTION}

The cooperative learning model of team game tournament (TGT) is one of the easy-to-apply cooperative learning models involving the activities of all students without any degree of status, involving the role of students as peer tutors, and containing the elements of game and reinforcement (Hamdani, 2011). Learning using the TGT model begins with class presentation, group learning, games, matches and group awards (Rusman, 2012). The TGT learning model has a student center characteristic focused on constructing student knowledge, where students are expected to find important 
information for constructing their own knowledge (Slavin, 2010). Somestudy results show that active learning can improve student academic performance (Michael, 2006; Freeman, et al., 2007; Chaplin, 2009; in Hamdan, 2013); improve the ability of critical thinking and attachment of students with the field of science, as well as develop a positive attitude in learning (O'Dowd \& Aguilar-Roca, 2009; in Hamdan, 2013).

Based on evaluation of clinical practice in the hospital, clinical instructor (CI) expressed that the students of our institution show weak mastery of anatomy and physiology of human body. Based on the results of a survey conducted on the faculty of nursing (FoN) of our institution in which the students have been exposed to all materials of anatomy and physiology (BiomedicalII and Nursing Basics I), most students reported that it was difficult to understand the anatomy and physiology of the nervous system. Students expressed their difficulties in understanding those subject because the complexity of the study materials.

Nur \& Wikandari (2000) explained that TGT has already implemented in various subjects. The most effectiveness was found in a subject which learning purpose was formulated sharply with one correct answer. Saptono, 2008 (in Judge, 2009) states that cooperative learning is a lesson that focuses on grouping students with different levels of academic ability into collaborative small groups whose members consist of 4-6 people with heterogeneous group structure. Through the TGT method students will actively communicate, think further, and allow students to learn more relaxed as well as foster responsibility, cooperation, healthy competition and learning involvement (Shoimin, 2014). The advantages of this learning method include increased student learning motivation and achieved better learning outcomes (Taniredja, 2011).

The general purpose of this research was to explain the effect of TGT application towards the learning motivation and achievement among nursing students, especially in the subject of nervous system anatomy and physiology. Specific objectives were: 1) identifying, analyzing, and explaining the effect of TGT implementation on learning motivation, and 2) Identifying, analyzing, and explaining the effect of TGT implementation on learning achievement.

\section{METHOD}

The population was all freshmen at nursing institutions in Surabaya. The affordable population was all nursing students of class 2015/2016 at FoN of Widya Mandala Catholic University Surabaya and FoN\& Midwifery of Universitas Nahdlatul Ulama Surabaya Population size in April 2017 was 208. Inclusion criteria was students who have received the study material of nervous system anatomy and physiology (through Biomedical II or Nursing Basics course) and active enrollment in the even semester of 2016/2017 academic year. Exclusion criteria were resigned in the middle of data collectionm period, did not attend all the face-to-face meeting sessions in classroom. After the selection process, only 143 student who were eligible to become study respondents.

Independent variable was TGT application, while the dependent variable was learning motivation and achievement. Data collection was conducted in June 2017, after final examination period. Before conducting the study, researcher team gave an explanation about the purpose and technical implementation of the study intervention and the benefits of study for freshmen. After all students understood and were willing to be study respondent, the researcher team then distributed the informed concent sheet to be signed. Pretest was conducted at the first meeting. Research team member were being facilitator by the time of data collection. The motivation questionnaire was distributed to be filled simultaneously. After completion, facilitator divided the respondents in groups of 6-8 students. Facilitator then presented the study materials and the respondents studied about it independently in groups for the next meeting. The facilitator then distributed 
the task description sheet and gave a brief explanation of the expected outcomes, outcomes of individual or group learning. Respondents were given the opportunity to ask to clarify the facilitator statements that felt less clear. At the second meeting, the respondents were given group assignment of the results of group discussions about the study materials that had been presented and discussed with the facilitator. The face-to-face meeting lasted for 100 minutes for each, 3 times a week. At the third meeting, facilitator conducted a game between groups according to teaching plan. Playing process included: 1) the students sat based on groups, 2) facilitator determined the students' number and placed them in the tournament table (equal competency): in each table, there was one game sheet, one answer sheet, one box of number card, and one sheet of game score; 3 ) one student withdrew a card to determine $1^{\text {st }}$ reader (highest number), and other students would be the challenger; 4) $1^{\text {st }}$ reader shuffled the card and took the topmost card, 5) $1^{\text {st }}$ reader read the question based on number on the card and tried to answer, if he gave wrong answer there was no punishment and the card was returned, but if he gave right answer then the card was saved as score evidence; 6) if the $1^{\text {st }}$ and $2^{\text {nd }}$ challenger had different answers, they could answer in turn, 7) if the challenger answer was wrong, he would be fined by returning the right answer card (if present); 8) then students changed position (in turn) with the same game procedure.

The facilitator then performed an assessment based on teaching plan and selected one of the best groups and rewards them. By the end of the fourth meeting, posttest was conducted by distributing motivation questionnaire and performed individual objective test for gaining the data of learning achievement. TGT result was all students actively involved in the learning process, they could increase positive mind, sensitivity, and tolerance toward others.

Motivation of learning is assessed by learning motivation questionnaire made by Aryanti with Cronbach's alpha $=0,940$ (UNNES, 2010) used Likert scale with details: strongly agree (score 5), agree (score 4), neutral (score3), disagree (score 2), and strongly disagree (score 1). This questionnaire consists of 25 items by element of intrinsic and extrinsic motivation to learn, namely: the level of discipline to follow the learning process, the level of diligence to do the task, the frequency of independent learning in doing the task, the impulse to learn and achievement. Each item is rated on a Likert scale and scored according to the guideline stated in the variables operational definition and summed to get the total score which then put into statistical test (paired $t$ test). The research hypothesis will be accepted if the significance of data less than $\alpha(0.05)$.

The result of the students' learning achievement was evaluated from the objective test developed by the researcher team which amounted to 50 multiple choice questions based on the anatomy and physiology theory of the nervous system by scoring one if respondent got the score 2 and scoring one if he got the score 0 . The score of learning achievement was summed, then put into statistical test (Mann-Whitney test). The research hypothesis will be accepted if the significance of data less than $\alpha(0.05)$.

The researched team followed ethical assessment in the FoN of Airlangga University to obtain ethical clearance (number: 449-KEPK). Other ethical aspects in this study were informed concent, anonimity, confidentiality, freedom, justice, baneficence, and non-maleficence. 


\section{RESULTS}

Sample size was 143. Demography characteristic of responmdents were shown in Table 1 below.

Table 1. Demography characteristic

\begin{tabular}{lcc}
\hline Characteristic & $\begin{array}{c}\text { Frequency } \\
(\mathrm{n}=143)\end{array}$ & $\begin{array}{c}\text { Percentage } \\
(\%)\end{array}$ \\
\hline
\end{tabular}

1. Age (years old)

$\begin{array}{lcc}\text { a. } 17 & 4 & 2,7 \\ \text { b. } 18 & 29 & 20,3 \\ \text { c. } 19 & 95 & 66,4 \\ \text { d. } 21 & 5 & 3.5 \\ \text { e. } 20 & 8 & 5,7 \\ \text { f. } 23 & 2 & 1,4\end{array}$

2. Gender
a. Female
122
85,3
b. Male
21
14,7

3. Marital Status

Single $\quad 143 \quad 100$

4. Living with

\begin{tabular}{|c|c|c|}
\hline $\begin{array}{l}\text { a. Extended } \\
\text { family }\end{array}$ & 10 & 7 \\
\hline b. Parents & 97 & 67,8 \\
\hline c. Sibling & 5 & 3,5 \\
\hline d. Alone & 24 & 16,8 \\
\hline e. Friend & 7 & 4,9 \\
\hline
\end{tabular}

\section{Housing Status}

a. Yearly rent

b.Monthly rent

c. Owner

\section{Reasons for \\ choosing nursing \\ major}

. Dream

b. Curious

c. Parental advice

d. Personal desire

e.Parental motivation

f.Siblings'

motivation

g. Inner motivation

h. Getting job easily

i.Scholarship

program

j. Caring to others

k.Personal preference

1.Unaccepted in

desiring college

Of the 143 respondents, most were 19 years old $(58 \%)$, females $(85.3 \%)$, single

5,3

00

7

3,5

4,9

3,5

29,4

67,1

$\begin{array}{ll}42 & 29,4 \\ 96 & 67,1\end{array}$

$96 \quad 67,1$

(100\%), living with parents (67.8\%), in their own home (67.1\%). In this study, the majority of nursing students chose nursing major because it was their dream (23.8\%).

The result of Shapiro-Wilk test showed that pretest and posttest learning motivation data were normally distributed $(\mathrm{p}$ $=.197$ ). Learning motivation data before and after study was shown in Table 2 below. 
Table 2.Laerning Motivation Cross-tab

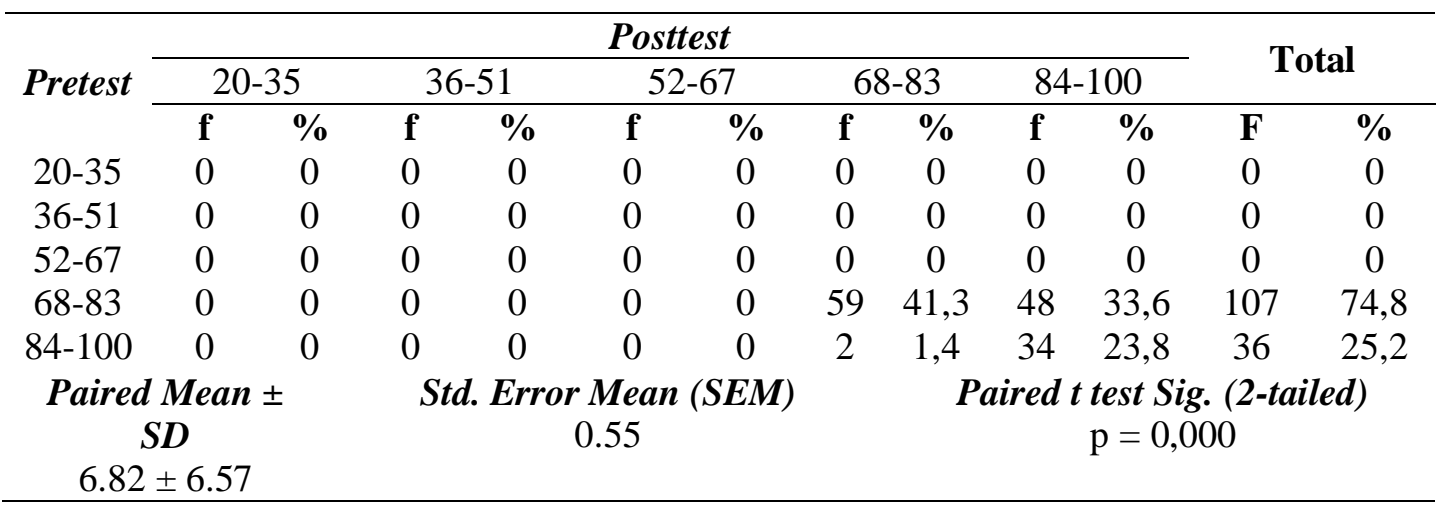

There were 48 respondents $(33.6 \%)$ who experienced an increase in the score of learning motivation, from 68-43 to 84-100. In addition, there were 2 respondents $(1.4 \%)$ who experienced a decrease in learning motivation score, from 84-100 to 68-83. 34 respondents (23.8\%) whose learning motivation score remained at the value of 84 100.

The result of paired $t$ test showed that the paired mean value was 6.82 with SD 6,57 . The mean value of pretest and post-test was 79.3 and86.1 respectively. SD value less than meanindicates a low deviation from the observed data. The SEM value of 0.55 indicates that mean was representative for describing the overall data.

The result of paired $t$ test test showed that TGT application has a significant effect toward learning motivation among nursing students $(\mathrm{p}=.000)$, especially in the subject of nervous system anatomy and physiology. This learning method was proved to be effective forincreasing learning motivation.

The Kolmogorov-Smirnov test results showed that post-test-only learning achievement data was abnormally distributed $(\mathrm{p}=.004)$. Learning achievement data before and after study is presented in Table 3 below.

Table 3. Learning Achievement

\begin{tabular}{lcc}
\hline Score & \multicolumn{2}{c}{ Learning Achievement } \\
& n & \% \\
\hline$\leq 44$ & 25 & 17.5 \\
$45-54$ & 42 & 29.3 \\
$55-58$ & 8 & 5.6 \\
$59-62$ & 8 & 5.6 \\
\hline
\end{tabular}

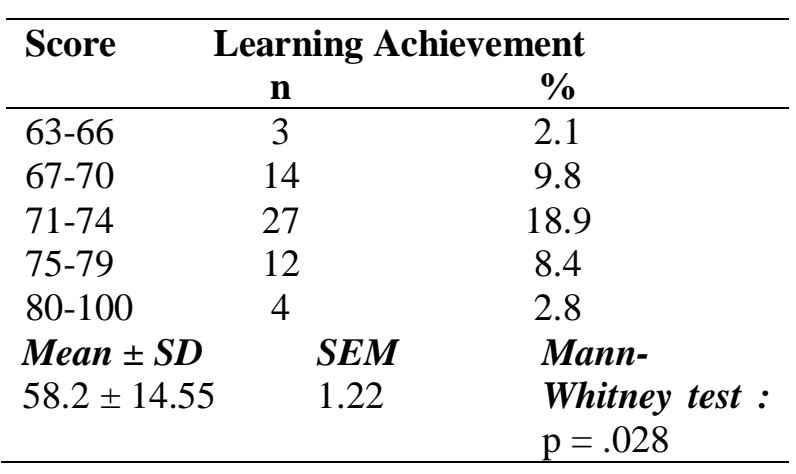

The score of the most dominant posttest learning achievement was in the 45-54 range $(29.3 \%)$. Respondents who got high score in range of 80-100 was 4 students only (2.8\%). Respondentswho got low score in range of $\leq 44$ were 25 students $(17.5 \%)$. The results of descriptive statistic showed that mean value was 58.2 with SD 14.55. SD values which less than mean indicates a low deviation from the observed data. The SEM value of 1.22 showed the value of mean was representative for describing the overall learning achievement data.

Mann-Whitneystatistical test was used because the data was abnormally distributed. TGT application has a significant effect toward learning achievement $(\mathrm{p}=.028)$. This learning method was proved to be effective for improving learning achievement among nursing students, especially in the subject of nervous system anatomy and physiology.

\section{DISCUSSION}

\section{Apllication of TGT learning method towards Learning Motivation}


Study results showed that there was sisgnificant effect of TGT application towards learning motivation among nursing students, especially in learning about nervous system anatomy and physiology $(\mathrm{p}=.000)$. In this study, researchers argue that high motivation in after learning by TGT method because students are involved in the learning process actively. The TGT learning method was fun because of the games that make students active. This is consistent with the results of the interviews when conducting the data collection that students feel energized and prefer the kind of learning that involves games.Students who receive knowledge with joy in their studies will develop an increase in learning motivation that ultimately affected their study achievement. One of the fun things in learning is doing it through playing game. If this activity made the students relaxed, conducive, not too stressed or tired, and educational games can be accepted by the students, their motivation in learning will increase, because of the increase in metabolic work of the students' brains (Serevina, 2009).According to Suprijono (2010), by creating a positive learning environment it will foster motivation and interest of students to follow the learning process. Especially in cooperative learningenvironment that is very influential on achievement of learning outcomes. This opinion is in line with the results of research from Warmansyah (2016) about the influence of cooperative learning methods and learning motivation in the topic of learning mathematics. His conclusionwas there was significant effect of interaction between learning method and learning motivation learning mathematics.

In this study there were 48 respondents $(33.6 \%)$ who experienced an increase in the value of learning motivation. This increase might be supported by the fact that the majority of respondents living with their parents. According to Ahmadi (2007) family is a small social group consisting mostly of father, mother, and children with relatively fixed social relationships based on blood or adoption bonds. Wirowidjojo (in Slameto, 2010) statedthat family is the first and foremost educational environment. The way parents educate is the effort that parents do in treating and making their child learning. This study results also supported by Rahmawati (2016) who studied about the factors affecting the learning motivation of high school students on the economic subjects. One of her research conclusions is that family environment has a positive and significant impact on students' learning motivation.

Researcher team concluded that other factor determined the increase in learning motivation of students is because TGT is a cooperative learning method like Student Team Achievement Division (STAD). Cooperative learning shows activities and interaction among students to be motivated by each other. This is congruent with the study of Wyk (2012). Wyk stated that cooperative learning method by utilization of STAD method resulted in better learning achievement and highest motivation to learn about

There were also 2 respondents (1.4\%) who experienced a decrease in learning motivation. This possibly happened due to their reason for entering nursing department was because of their parents' wishes. This signifies being a nurse rather than the respondent's interest. Interest is the feeling of liking to a thing or activity without the coercion of its work (Slameto, in Djaali, 2008). Good interest and self-awareness to the field of learning will keep the students engage to the learning activities so that they can master the lessons and in the end they can achieve good learning outcomes (Djaali, 2008). Interest that can support learning is an interest to the study material / subject and to the teacher/facilitator who teaches/delivers it. If the students are not only uninterested with the materials / subjects but also to the teacher, then the students will not want to study. This opinion is in line with Hidayat's research (2015) about the correlation between students' interest and aspirations with the learning motivation among nursing students at Muhammadiyah University of Surakarta. His study results showed that interest and aspirations affected learning motivation.

\section{Apllication of TGT learning method towards Learning Achievement}


Results showed that there was a significant effect of TGT application towards learning achievement among nursing students, especially in learning about nervous system anatomy and physiology $(\mathrm{p}=.028)$. This result could occur because of the nature of TGT learning method which was tournament and fun, thus making the students to be more motivated in following the learning process. In the TGT learning process each student in the group has the responsibility to get the highest score in the tournament. Each student competes to make her group wins. According to Sardiman (2004), high motivated students will always be eager to learn and will always increase the intensity of their learning effort. This opinion is in line with the research conducted by Putra et al (2013) about the effect of cooperative learning model type TGT towards students' learning outcomes. The results of their study indicate that there was an increase in students' learning outcomes in the classroom by using cooperative learning model type TGT. Researchers believed this results are also influenced by student activities. TGT which is a type of cooperative learning method improves student learning activity and their activeness during the learning process. This is congruent with the study of Wyk (2011), he stated that the intervention group's result was better than the control group.

Slavin in Rusman (2011) presented two reasons why cooperative learning strategies should be encouraged. Several study results proved that: (1) the use of cooperative learning can improve student's learning achievement and simultaneously can improve social relationship, cultivate tolerance and attitude, and appreciate the opinion of others, (2) cooperative learning can fulfill the requirement of student in critical thinking, and integrate their knowledge with experience. This is in accordance with the opinion of Damon and Murray (in Slavin, 2008) that the clever student interaction with the less intelligent students in a group of students can make them work together, explain and listen to each other so that they get better understanding about the study material. Students who do not understand the subject matter can be helped by their friends who areunderstand better through cooperative learning activities and exchanging information that takes place during the learning process through TGT learning method. This is in line with research conducted by Lovieana (2014) on the application of TGT learning method as an effort to increase learning activity on basic competence of vocational high school students. Study results showed that TGT can increase student activity in groups cooperation and give each other encouragement among students by using skills that have been trained in learning process.

This study results showed that the most dominant posttest study result of learning achievement was in score of 45-54 as many as 42 respondents (29,3\%). Based on the results of post-intervention interviews towards them, we believed that the respondents have considered the subject matter of nervous system anatomy and physiology was a difficult lesson, so that they have less interest in it. As stated by Nasution (1997): "interest influences the learning process and outcomes, it is not to be questioned that if someone is not interested in learning something then it cannot be expected that he will work well in learning it; on the contrary if someone learns with interest, it can be expected that the results are good."This opinion is in line with the study of Kurnia et al (2015) about the effect of facilities and interest in learning on the results of learning subjects of marketing in vocational high school students. The study results concluded that there was a significant effect of the students' interest on their learning outcomes.

There were 4 respondents $(2,8 \%)$ got score in the range of 80-100. Based on demographic data, these 4 respondents chose the department of nursing because of ideals, preference, and desires alone. This can explain that the personal determinant is a part of one's interests. Interest in learning showsa high tendency to learn, gain information, knowledge, proficiency, through effort, teaching or experience. Learning with interest will encourage learners to learn better than learning withoutit,Interest arises when students are interested in something because it suits their needs or feel that something they 
will learn is meaningful to themselves (Setiabudi, 2008).

Surya in Sudrajat (2011)stated that interest in something learned and influences of subsequent learning will influence the acceptance of new interests. So interest in something is the result of learning and encourages further learning. This opinion was in line with a study conducted by Budiwibowo (2016) about the correlation of student learning interest with learning outcomes in junior high school. This study explained that the students' interest in the subjects of social studies with student learning outcomes had a strong correlation.

In this study there were 24 respondents $(16,8 \%)$ have reasons to enter nursing department because of aspiration, self-desire and preference, but they got score $\leq 44$. The influence of learning outcomes on respondents not only from interest alone but also because of the ability / talent of each individual. According to Chaplin and Reber as quoted by Syah (2006) in his book "Learning Psychology" which states that talent is a potential ability possessed by someone to achieve success in the future. In this case, talent could be a factor that greatly influences the success of learners. This opinion was also in line with the study of Putra and Sucitra (2015) about the correlation of intelligence with the learning outcomes in mathematic subject of students in elementary school. Results showed that there was a significant correlation between intelligence with mathematics learning outcomes, the higher level of inteligence then the higher mathematics learning outcomes will be.

\section{CONCLUSION}

Application of TGT learning method was effective forimproving learning motivation and achievement in nursing students, especially for learning about nervous system anatomy and physiology. For lecturers, before preparing the teaching materials we should conduct a survey about the needs and then determinesuitable learning methods for our students. Students should increase their learning independence and interest to be more cooperative in applying TGT learning method. Nursing institutions could do a trial of TGT learning method on other subjects. Other researchers could do advance study by using the paradigm of mixes-methods to overcome the weakness of methodology in this study. Study limitation was by using big sample size and many groups played TGT in one time, there was a possibility that some students were not actively involved in the learning process.

\section{REFERENCES}

Ahmadi, A. (2007). Psikologi Sosial. Jakarta: PT Rineka Cispta.

Ali, M. (1997). Pengantar Penelitian. Bandung: Angkasa

Ariyanti, I. (2010). Pengaruh Minat Dan Motivasi Belajar.Terhadap Prestasi Belajar Mahsiswa Program Studi Pendidikan Akutansi Universitas Negeri Semarang.Skripsi. Diunduh dari ib.unnes.ac.id/3186/1/6382.pdf

Budiwibowo, S. (2016). Hubungan Minat Belajar Siswa dengan Hasil Belajar IPS di SMP Negeri 14 Kota Madiun. Jurnal Studi Sosial Volume 1 Nomor 1 hal 60-68. Diunduh Pada Tanggal 14 September 2017 dari http://ejournal.ikippgrimadiun.ac.id/index.p $\mathrm{hp} /$ gulawentah.

Dalyono, M. (2009). Psikologi Pendidikan. Jakarta : Rineka Cipta

Djaali. (2008). Psikologi Pendidikan. Jakarta: Bumi Aksara.

Dimyati dan Mudjiono. (2006). Belajar dan Pembelajaran. Jakarta: PT Rineka Cipta.

Hakim, Lukmanul. (2009). Perencanaan Pembelajaran. Bandung: Wacana Prima.

Hamdan, N., Mcknight, P., Mcknght, K., \& Arfstrom, K.M. (2013). The Flipped Learning Model: A White Paper Based On The Literature Review Titled A Review Of Review Of Flipped Learning. Flipped Learning Network. Diunduh Pada Tangga 27 Agustus 2014.

Http://Www.Flippedearning.Org/Cms/ Lib07/VA01923112/Centricity/Domain /41/Litreview_Flippedlearning.Pdf

Hamdani, (2011).Strategi Belajarmengajar. Bandung: CV Pustakasetia.

Hasan, S. (2012). Pengaruh Strategi Pembelajaran Kooperatif STAD, TGT, Dan Integrasi STAD dan TGT 
Terhadap Keterampilan Metakognisi, Berpikir Kritis, Dan Hasil Belajar Kognitif Ipa-Biologi Sd Kelas V Di Kota Ternate. Desertasi. Diunduh dari http://library.um.ac.id.

Hidayat, R., Muhlisin, A., Dewi, E. (2015) Hubungan Antara Minat Dan CitaCita Dengan Motivasi Belajar Mahasiswa Program Studi S1 Keperawatan di Universitas Muhammadiyah Surakarta. Skripsi. Diunduh dari http://eprints.ums.ac.id/37324/.

Kurnia, U., Herkulana, Khosmas, F. Y. (2015). Pengaruh Fasilitas dan Minat Belajar Terhadap Hasil Belajar Mata Pelajaran Pemasaran Siswa Smk Negeri 1 Pontianak. Jurnal Pendidikan dan Pembelajaran Vol 4, No 9. Diunduh tanggal 15 September 2017 dari http://jurnal.untan.ac.id/index.php/jp $\mathrm{dpb} /$ article/view/11420/10822.

Lovieana, L. (2014). Penerapan Model Pembelajaran Teams Games Tournament(TGT) Sebagai Upaya Meningkatkan Aktivitas Belajar Pada Kompetensi Dasar Memilih Jenis Penggandaan Dokumen Yang Sesuai Di Smk Nasional Pati. Skripsi. Diunduh dari http://lib.unnes.ac.id/22329/1/710140 9003-s.pdf.

Nasution. (1997). Berbagai pendekatan dalam Proses dan Mengajar. Jakarta: Bumi Aksara.

Nur, M. dan Wikandari, P.R. (2000). Pengajaran Berpusat kepada Siswa danPendekatan Konstruktivistik dalam Pengajaran. Surabaya: Universitas Negeri Surabaya. (web)

Putra, A. H., Sucitra, W. (2015). Hubungan Intelegensi dengan Hasil Belajar Matematika Siswa Kelas V SD Negeri 68 Pekanbaru. JPM IAIN Antasari Vol. 02 No. 2 hal 118.(web)

Putra, E. O., Achmad,A., Marpaung, R. R. T. (2013). Pengaruh Model Pembelajaran Kooperatif Tipe Tgt Terhadap Hasil Belajar Siswa. Jurnal Bioterdidik Vol 1 No 7. Diunduh tanggal 14 September 2017 dari http://jurnal.fkip.unila.ac.id/index.ph $\mathrm{p} / \mathrm{JBT} /$ article/view/2161.

Rahmawati, R. (2016). Faktor-Faktor yang Mempengaruhi Motivasi Belajar Siswa Kelas X SMA Negeri 1 Piyungan Pada Mata Pelajaran Ekonomi Tahun Ajaran 2015/2016. Skripsi. Diunduh dari http://eprints.uny.ac.id/41152/1/RIM A\%20RAHMAWATI\%20(SKRIPSI \%20FULL).pdf

Robert E. Slavin. (2010). Cooperative Learning: Teori, Risetdanpraktik. Bandung: Nusa Media.

Rusman. (2011). Model-Model Pembelajaran Mengembangkan Profesionalisme Guru. Jakarta: PT. Rajagrafindo Persada.

Rusman.(2012). Model -Model Pembelajaran. Depok: PT Ajagrafindo Persada.

Sardiman, A. M. (2004). Interaksi dan Motivasi Belajar Mengajar. Yogjakarta: Rajawali Press.

Sardiman. (2010). Interaksi dan Motivasi Belajar Mengajar. Jakarta: Pt. Raja Gravindo Perada.

Setiabudi, F. (2008). Pengaruh Pengalaman Praktik, Pengetahuan Tentang Lapangan Dan Minat Belajar Terhadap Kesiapan Kerja Siswa SMK: online Email : Library@lib.unair,ac,id;

Library@unair.ac.id Undergraduated theses Airlangga University: Dharmawangsa dalam Surabaya Indonesia.

Serevina, V. ( 2009). Positive Influence between Outbound Activity in Physics Learning with Student Studying Motivation.J akarta: State Unversity of Jakarta. (web)

Shoimin, Aris. (2014). 68 Model Pembelajaran Inovatif Dalam Kurikulum 2013. Yogyakarta: Ar-Ruzz Media.

Slameto. (2010). Belajar dan Faktor-Faktor Yang Mempengaruhinya. Jakarta: PT Rineka Cipta.

Slavin, R. E. (2008). Cooperative Learning, Teori, Riset dan Praktik (Alih Bahasa Nurulita Yusron). Bandung: Nusa Media. 
Sudrajat, A. (2011). Model Pembelajaran Langsung (Direct Instruction). Diunduh tanggal 14 September 2017 dari https://www.academia.edu/15336933 /Model_Pembelajaran_Langsung_Di rect_Instruction.

Sugihartono, dkk. (2007). Psikologi Pendidikan. Yogyakarta: UNY Press.

Suprijono, A. (2010). Cooperative Learning Teori \& Aplikasi PAIKEM. Yogyakarta: Pustaka Pelajar.

Syah, M. (2006). Psikologi Belajar. Jakarta: PT Raja Grafindo Persada.

Taniredja, Tukiran. Dkk. (2011). ModelModel Pengembangan Inovatif. Bandung: Alfabeta.

Uno, Hamzah B. 2009. Model Pembelajaran Menciptakan Proses Belajar Mengajar yang Kreatif dan Efektif. Jakarta: PT Bumi Aksara.
Warmansyah, P. (2016). Pengaruh Metode Pembelajaran Kooperatif dan Motivasi Belajar Terhadap Hasil Belajar Matematika. Jurnal Pendidikan Usia Dini Volume 10 Edisi 1 hal 99-120. https://goo.gl/C5UYZf

Wyk, M. M. V. (2011). The Effects of Teams-Games-Tournaments on Achievement, Retention, and Attitudes of Economics Education Students. Journal of Social Sciences Volume 26 Issue 3 hal 183-193. https://goo.gl/7FzwQy

Wyk, M. M. V. (2012). The Effects of Teams-Games-Tournaments on Achievement, Retention, and Attitudes of Economics Education Students. Journal of Social Sciences Volume 33 Issue 2 hal 261-270. 